Case Reports

\title{
'Floor Layers Foot' - An Occupational Bursa
}

\author{
Capt B Robertson" \\ LRCP, MRCS, RAMC
}

\author{
Maj I R Haywood ${ }^{\text {** }}$ \\ $M B, B S, F R C S, R A M C$ \\ Cambridge Military Hospital, Aldershot
}

SUMMARY: A case of an occupational bursa of the forefoot resulting from prolonged pressure as a floor layer is described. It is compared with bursae occurring in similar occupations.

A 24 year old man presented with a large cystic swelling on the dorsolateral aspect of his right foot that had been present for some seven months (Fig. 1). This was considered to be an adventitious bursa which had arisen as a result of his occupation as a floor-layer.

At operation on 3 February 1977 the forefoot was explored through a transverse incision over the swelling and a thick walled bursa was found between the superficial and deep fibres of the extensor retinaculum. The bursa contained clear bloodstained serous fluid and was excised. Macroscopically the specimen measured $6 \times 5 \times 4 \mathrm{~cm}$ and its wall was $0.7 \mathrm{~cm}$ thick. Histological examination of the specimen showed it to be a cyst with a fibrocollagenous wall and a smooth non-synovial lining. Reactive vascularisation was also seen around the

*. Now General Practitioner, Aldershor, Hanis,

** Now Lt Col, Consultant in Surgery, BMH Munster.

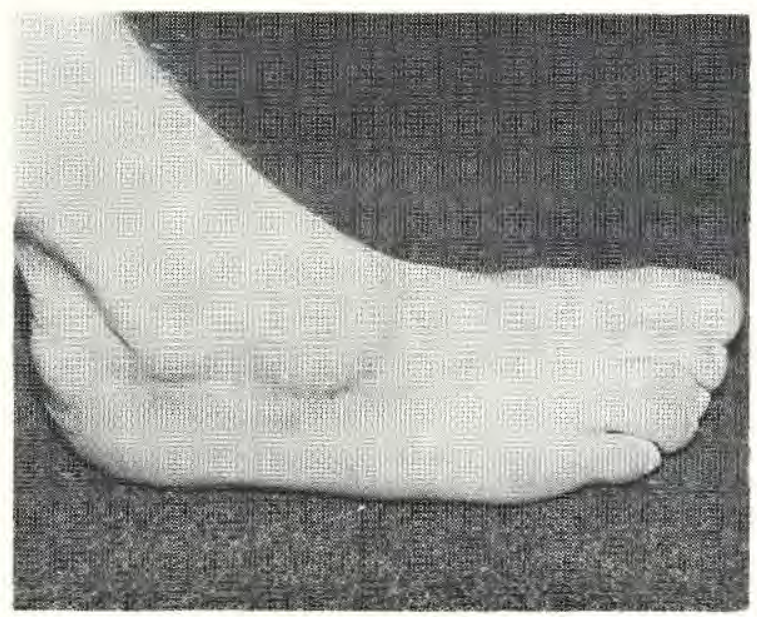

Fig. 1 The Bursa wall and the histological picture is consistent with traumatic bursitis.

Discussion
Bursae are of two distinct types. There are to present in the normal anatomy and adventition bursae such as the case described which develorim response to repeated friction or prolonged pressert $\vec{\varepsilon}$

Two bursae of the foot are commonly descrisige These are the anatomical retro-calcaneum bursa ฌn the adventitious retro-achilles bursa. The latter been described associated with ill-fitting footwick and also in miners due to their kneeling positiô. Many reports have been made about occupatiot bursae in miners particularly those involving $\Phi$ knees $^{1-3}$. Hunt (1974) also describes an adventition bursa in miners over the tarsal bones which is vero similar to the present case but somewhat mor laterally placed ${ }^{1}$.

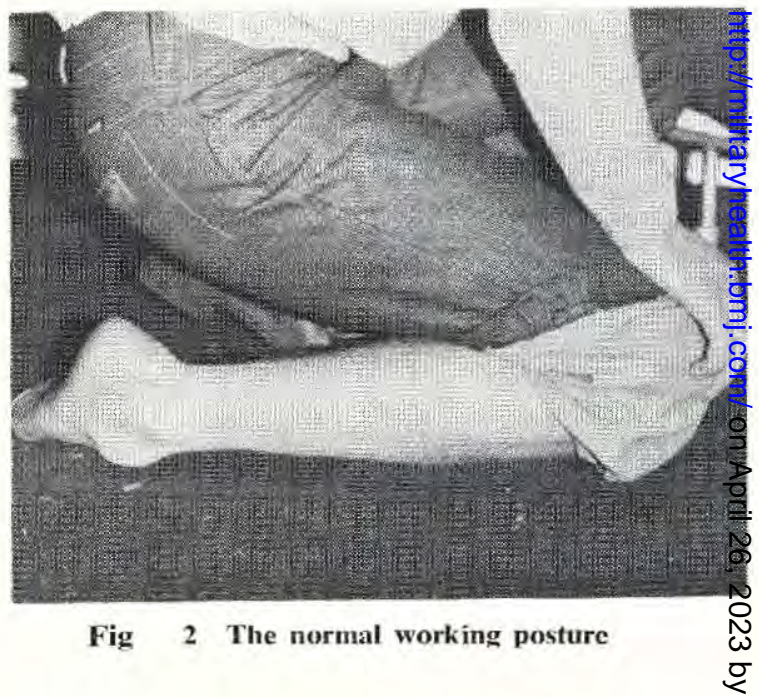


Floor-layers knees and ankles are subjected to very similar stresses as kneeling miners so it is reasonable to expect similar lower limb bursae to occur in both occupations. Mikheev (1968) described bursitis in the knees of parquet floor layers on Moscow building sites, however, no mention is made of any ankle or foot bursae ${ }^{4}$. Fig. 2 illustrates the usual working posture of the case described and shows how this area of the foot makes constant contact with the floor on which he is working.

\section{Acknowledgements}

We thank Brig P K Coakley FRCS/RAMC for permission to publish this case, Lt Col Coull FRCS, RAMC and Col J B Stewart MRCPath, RAMC. for much helpful advice. The photographic work was by the Department of Clinical Measurements, Cambridge Military Hospital and the Department of Medical Illustration, Royal Army Medical College, London.

\section{REFERENCES}

1 HUNT T A. Tissue reaction to pressure stresses in miners, Practitioner 1974; 213: 189-194.

2 Sharrard W J. Haemobursa in kneeling miners, Proc Roy Soc Med 1951; 54: 1103-4.

3 Sharrard W J. Pressure effects on the knee in kneeling miners. Ann Roy Coll Surg Eng 1965; 36: 309-324.

4 MIKHEEV V A. Occupational genual bursae of parquet-flooring workers. Gig Tr Prof Zabol 1969; 13: $45-6$.

\section{'THE SCIENTIFIC BASIS OF THE CARE OF THE CRITICALLY ILL'}

An international meeting will be held in Manchester, 5-8 September 1984, to honour the retirement of Professor H B Stoner, MD, FRCPath, FRCS, as Director of the Medical Research Council Trauma Unit.

Topics for discussion include: The local response to injury, metabolic changes after injury, the nutrition of the critically ill, role of the central nervous system in the response to injury, the pathogenesis of complications and the modification of the response to injury.

For further details please write to: Dr R A Little, MRC, Trauma Unit, Stopford Building, University of Manchester Medical School, Oxford Road, Man chester M13 9PT. Tel: 061-273 4661. 